\title{
A Study on the Effects of Creativity Training Program on Creative Behaviors of Children ${ }^{1}$
}

\section{Zeynep Dere ${ }^{2}$}

\section{Esra Ömeroğlu ${ }^{3}$}

Type/Tür: Research/Araştırma Received/Geliş Tarihi: $10 / 08 / 2017$

Accepted/Kabul Tarihi: 14/02/2018

Page numbers/Sayfa No: $1-15$ Corresponding Author/İletişimden Sorumlu Yazar: zeynepdere@gmail.com

\section{$\checkmark$ iThenticate}

This paper was checked for plagiarism using iThenticate during the preview process and before publication. / $\mathrm{Bu}$ çalışma ön inceleme sürecinde ve yayımlanmadan önce iThenticate yazılımı ile taranmiştır.

Copyright (C) 2017 by Cumhuriyet University, Faculty of Education. All rights reserved.

\begin{abstract}
This study aimed to investigate the effects of creativity training program on children's creative behaviors. In this study, a quasi-experimental model was used. The model was constituted with a pre-test and posttest control group. The study group which was chosen via typical sampling method consisted of totally 30 children who were students in two separate nursery classes. 16 of them were in experimental group and 14 of them were in control group. Creative Behavior Observation Form was applied to both groups as pre-test and post-test. Creative Training Program which consisted of 36 activities to support creative thinking of the children in the experimental group was applied 3 days a week for 12 weeks by the researcher. Control group students were applied Preschool Education Program of National Ministry Education by their teacher. After posttests, Creative Behavior Observation Form Activities were re-applied to experimental group to determined the retention of Creativity Training Program and children's behaviors were evaluated by Creative Behavior Observation Form Paired sample t-test was used in order to determined if there were significant differences between pre-test and post-test obtained from observation form of the experimental and control group; independent sample t-test was used in order to determined if there was any difference between the mean scores in pre-tests of the experiment group and control group. ANCOVA analysis was used to compare post-test means based on the dimensions where significant differences were found as a result of pretest of the experimental and control groups. Significance level was identified as $\mathrm{p}<.05$ for all the analysis throughout the study. The results showed that the Creavity Training Program affected chidrens' creavity behaviors in positive way. The results of retention test indicated that the effect of the program was effective.
\end{abstract}

Keywords: Creativity, creativity training, creative behavior observation form, preschool education, early childhood

\section{Suggested APA Citation/Önerilen APA Atıf Biçimi:}

Dere, Z., \& Ömeroğlu, E. (2018). A study on the effects of creativity training program on the creative behaviors. Cumhuriyet International Journal of Education, 7(1), 1-15. Doi:10.30703/cije.333901

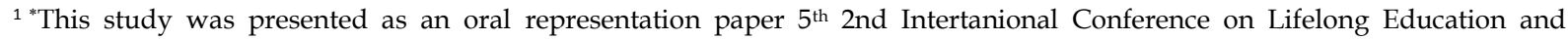
Leadership in Latvia, 21-23 July, 2016. This study was producud from a PhD dissertation called Examination of the Affects of Creativity Training Program Applied to Nursery Students on Their Creative Behaviours.
}

${ }^{2}$ Assist. Prof. Dr., Bozok University, Yozgat/Turkey Yardımcı Doç. Dr., Bozok Üniversitesi, Yozgat/Türkiye E- mail: zeynep.dere@bozok.edu.tr ORCID ID: orcid.org/0000-0001-6078-7077

\footnotetext{
${ }^{3}$ Prof. Dr., Gazi University, Ankara/Turkey Profesör Dr., Gazi Üniversitesi, Ankara/Türkiye E- mail: esra.omeroglu@gmail.com ORCID ID: orcid.org/0000-0000-0000-0000
} 


\title{
Yaratıcılık Eğitim Programının Çocukların Yaratıcı Davranışlarına Etkisinin İncelenmesi
}

\begin{abstract}
Öz
$\mathrm{Bu}$ araştırmada, çocuklar için geliştirilen yaratıcılık eğitim programının, çocukların yaratıcı davranışlarına olan etkisi belirlenmiştir. Çalışmada için öntest-son test kontrol gruplu yarı deneysel desen kullanılmıştır. Yaratıcılık Eğitim Programı́nın çalışma grubunu, tipik örnekleme yöntemiyle seçilen iki farklı anasınıfında eğitim gören 30 çocuk oluşturmaktadır. Araştırmanın deney grubunda 16, kontrol grubunda da 14 çocuk bulunmaktadır. Her iki gruptaki çocuklara ön-test ve son-test olarak araştırmacı tarafından Yaratıcı Davranış Gözlem Formu uygulanmıştır. Yaratıcılık Eğitim Programının 36 etkinliği, haftada 3 gün olmak üzere 12 hafta boyunca araştırmacı tarafından deney grubundaki çocuklara uygulanmıştır. Kontrol grubundaki çocuklara ise anasınıfı öğretmeni tarafından Milli Eğitim Bakanlığı Okul Öncesi Eğitim Programı'nın uygulanmasına devam edilmiştir. Son testlerin uygulanmasının ardından, Yaratıcılık Eğitim Programı'nın kalııılığını belirlemek için deney grubuna Yaratıcı Davranış Gözlem Formu Etkinlikleri tekrar uygulanmıştır ve çocukların davranışları Yaratıcı Davranış Gözlem Formu ile değerlendirilmiştir. Kontrol grubu ve deney grubunun gözlem formundan aldıkları ön-test ile son-test ortalamalarının arasında anlamlı farklılık olup olmadığını belirlemek için ilişkili örneklemler $t$ testi, kontrol grubunun ve deney grubunun ön-test ortalamaları arasındaki farkı belirlemek amacıyla bağımsız örneklemler $\mathrm{t}$ testi, kontrol ve deney grubunun ön-test sonuçları arasında anlamlı fark bulunan boyutlardan elde edilen son-test ortalamaların karşılaştırmak için ANCOVA, kullanılarak veriler analiz edilmiştir. Çalışmada tüm analizler için anlamllık düzeyi $p<.05$ olarak belirlenmiştir. Elde edilen verilere göre, Yaratıcılık Eğitim Programı çocukların yaratıcı davranışlarını olumlu yönde geliştirmektedir. Kalıcılık testi sonuçlarına göre de Yaratıcılık Eğitim Programı'nın etkisi devam etmektedir.
\end{abstract}

Anahtar Kelimeler: Yaratıcılık, yaratıcılık eğitimi, yaratıcı davranış gözlem formu, okul öncesi eğitim, okul öncesi dönem

\section{Introduction}

Creativity means obtaining a product that no one else has released before. Therefore, creativity yields unique products. Creativity implies going to beyond the boundaries while ensuring that the new path is, at the same time, acceptable. It is an ability to see the problems and establish unique ideas with a talent to reach solutions from ideas (Koster, 2001, p. 86; Sungur, 1997, p. 43). It is necessary to create an atmosphere for the children in which their special skills are supported and they are encouraged to be creative (Myers, 2004, p. 429). In other words, constructs of creativity are attitude, process, product, skills, and set of environmental conditions (Brown, 1989, p. 3; Schirrmacher, 2006, p. 5). Creativity develops in several stages for the children.

Creativity starts at early years of life. Children begin to use their creativity while solving problems as well as discovering their toys, environments and parts of their bodies (Schirrmacher, 2006, p. 6). Creativity of the children relies on their imagination. First phase of imagination is the process in which a child believes that 
everything such as white clouds in the sky, beaming rivers and sugar coated houses are real. In the second phase, the child starts to comprehend facts by asking why and how questions. In this phase, the child is able to relate reasons and results of the facts. In the third phase, the child now knows the facts in the word (Torrance, 1962, p. 85-86). Children are able to clearly display their creativity and produce ideas. They gain new experiences and acquire some gaining using their creativity (Gerrig \& Zimbardo, 2005, p. 307; Mayesky, 2002, p. 7).

Creativity shows up in a systematic way within a certain process. In the preparation process, individuals approach to problems in a conscious, logical and systematic way. They identify and define what they require or wish to realize (Csikszentmihalyi, 1997, p. 104). In incubation stage which follows the preparation process, individuals feel relieved. At this stage, individuals deliberately keep away from the problem and focus on the daily routine by ignoring the problem. Indeed, subconscious mind of the individual works to find a solution and analyze the phenomenon (Koster, 2001, p. 88). During illumination process, the solution or components of the solution unexpectedly appears to the conscious of the individual, this is an instance process. Creative individuals "find the answer" in this process. Problems related to solutions are found in the mind and become concrete. Individuals suddenly find the solution or decide what to do and develop it (Truman, 2011). Evaluation process focuses on conscious and logical thinking. In this process, decisions are taken when the obtained result meets the need, it is authentic or eligible (Torrance, 1977, p. 79).

Yldiz (2000) found out significant differences in favor of the children who benefited Creativity Training Program on the social and cognitive development of the children when she compared cognitive and social development of the children groups who were subject to and not subject to Creativity Training Program. Cheung (2010) studied effects of creative movement mentoring program. Results showed that creativity creative movement mentoring program could be supportive in terms of fluency dimension, flexibility dimension, originality dimension and elaboration dimension of the creativity of the children. Rizi, Yarmohamadiyan and Gholami (2011) studied effects of group plays on the creativity of the children, and found out that it was possible to increase children's creativity skills through group plays. In their studies to determine effects of Creativity Training Program designed for preschool children, Alfonso-Benlliure, Melendez and Garcia-Ballesteros (2013) revealed that significant positive developments were observed in the divergent thinking skills of preschool children. Results of the study by Dziedziewicz, Oledzk and Karwowski (2013) on the development of the children's creativity showed that training programs on drawing positively affects children's imagination and creativity. 
Taking into account the studies concerning creativity of preschool children, it is seen that creativity of the children is usually supported through game-plays, creative drama training programs, computer and technology training program, creative drawing training programs and project approaches. Creative Training Program designed for this study involves science, art, mathematic, preparation to reading/writing, music, and Turkish language, game-play, play and drama activities all in an integrated way. Furthermore, Creativity Training Program used in this study also supported creativity of the children through flexibility, fluency, originality and elaboration dimensions. The aim of this study was to explore the effects of Creativity Training Program on the creative behaviors of preschool children.

In this regard, answers were sought for the following questions:

Does Creativity Training Program designed for preschool children

- Have effects on creative behaviors of 5-6 years old children in terms of fluency dimension, flexibility dimension, originality dimension and elaboration dimension?

- Are they retentive in terms of fluency dimension, flexibility dimension, originality dimension and elaboration dimension of their creative behaviors?

\section{Model of the Research}

\section{Method}

The research data were attained by a "quasi experimental model with pre-test and post-test control group." The pretest-posttest control group pattern is one of the experimental designs commonly used in social sciences. Pretest-posttest is indicated as a two-factor experimental design with control group pattern, one repeated measures (pretest-posttest) and the others are test items (test control groups) in different categories. This particular subject is located in only one of the experimental or control groups (Büyüköztürk, 2007; Karasar, 2008). Children in the experimental group participated in a "Creativity Training Program" for 3 hours in a day, 3 days in a week, comprised of a total of 36 sessions for a total period of 12 weeks. Children in the control group, on the other hand continued their kindergarten education.

\section{Sample}

For the study group, two primary schools in Mamak District of Ankara were selected during spring term of 2013-2014 educational year. One of these schools was used for experimental group and the other for control group. Nursery classes at the schools were randomly selected.

\section{Creativity Training Program}

It consists of 36 activities that support the creative behaviors of children at the dimensions of flexibility, fluency, originality and enrichment. This program was prepared to integrate skills of the children to explore, invent, ask extraordinary question, produce extraordinary ideas, think in a flexible-fluent-original way, elaborate the products they generate and solve problems with reading writing exercises, music, Turkish language, play, drama, dramatization, mathematics, art, science and role plays and applied as groups plays for weeks. 


\section{Procedure}

There were 30 children in total, 16 of them were in experimental group and 14 of them were in control group.

Following the pre-test conducted by researcher and secondary observer, the researcher applied 12 weeks Creativity Training Program to experimental group for 3 days in a week and performed the post-test with secondary observer. The program started on 17 February 2014 and ended on 23 May 2014. Children in the control group were applied daily training program prepared in accordance with Preschool Education Program (2013) by their teachers. Creative Behavior Observation Form Activities were applied again four weeks after post-test as a test of retention and in order to determine effects of Creativity Training Program. Behaviors of the children recorded in the video cameras were watched and evaluated both by researcher and secondary observer by using Creative Behavior Observation Form.

Data collection instruments. "General Data Sheet" which includes generic data such as mother, father and the child and "Creative Behavior Observation Form" were used in order to collect study data.

General data sheet. First part of the form covers data such as gender of the children, number of siblings, if he/she received preschool education before; second part covers data on education level of their parents.

Creative behavior observation form. Developed by the researcher in order to evaluate creativity of 5-6 years old children in terms of fluency dimension, flexibility dimension, originality dimension and elaboration dimension. Creative Behavior Observation Form consisted of 26 items and four sub-dimensions. 257 children in total were sampled through stratified sampling method while determining validity and reliability of study group for Creative Behavior Observation Form. Cronbach's Alpha reliability coefficient was calculated in order to evaluate reliability of Creative Behavior Observation Form. Coefficient of the Form was 0.85 for flexibility, 0.88 for fluency, 0.77 for originality and 0.87 for elaboration. Coefficient for overall Creative Behavior Observation Form was 0.94. Findings indicate that Creative Behavior Observation Form is a valid and reliable instrument that can be used for scaling creativity of preschool children.

\section{Assessment}

Four activities were planned for observation of 26 items in the observation form. While the activities were fulfilled, observed behaviors were video recorded and then marked in the Creative Behavior Observation Form. Mean values of the observed behaviors in four activities were calculated. It is possible to make comments on how much creative these children are in comparison to other children based on the mean values of all dimensions. 
Secondary observer was provided training on how to evaluate activities and fill observation form. For pre-test, behaviors of the children in experimental and control groups were marked by the researcher and secondary observer after activities were completed.

\section{Analysis of the Data}

In order to determine the effectiveness of the Creativity Training Program given for the quasi experimental model, it was first examined whether the data showed normal distribution.

For this purpose, the Shapiro Wilk test, this gives biased results when the sample size is too low or too high, was used. For the normality, the skewness and kurtosis coefficients of the data set were examined and it was checked whether the obtained values were between -2 and +2 . Since the skewness and kurtosis coefficients calculated for each dimension included in the scale were within the specified range, it was accepted that the data showed normal distribution. For this reason, data were analyzed by parametric statistical analysis methods. Parametric statistical techniques were used to determine the effects of the Creativity Training Program developed for children attending kindergarten on children's creative behaviors (flexibility, fluency, originality and enrichment dimensions) after the distribution was found to be normal. Paired samples t-test was used to determine whether there was a significant difference between the pre-test and post-test scores of the control group and the experimental group in the observation form. Besides, independent samples t-test was carried out to determine whether there was a difference between the pre-test scores of the control group and the test group. Finally, data were analyzed using ANCOVA to compare post-test scores obtained from dimensions with significant differences between pre-test results. The first sub-objectives of the study were to investigate the "Creativity Training Program" developed for children attending the kindergarten, flexibility, fluency, originality and enrichment of the children who participated in the program and whether or not they were permanent in the dimensions of originality, flexibility, fluency and enrichment. For this purpose, ANCOVA and $t$ tests were used. For the second sub-goal of the study, the associated sample t-test was used to compare the scores of the children in the experimental group that were taken from the Post Test and Retention Tests of the Creative Behavior Observation Form.

\section{Results}

Within the frame of the research, there were a total number of 30 children selected for the study, 16 of them were in experimental group and 14 in control group. 9 of the 16 children in the experimental group were male and 7 of them were female; 7 of the 14 children in the control group were male and 7 were female. $62 \%$ of the children in the experimental group and $85.7 \%$ of the children in the control group had not attended a preschool institution before. 
Table 1

T-test Results Indicating Differences of Pre-test Mean Values in the Experimental and Control Groups Obtained from Creative Behavior Observation Form

\begin{tabular}{llllllll}
\hline Dimensions of & & & & & \\
Creativity & Group & $\mathrm{N}$ & $\mathrm{M}$ & $\mathrm{SS}$ & $\mathrm{t}$ & $\mathrm{sd}$ & $\mathrm{p}$ \\
\hline Flexibility & Experimental & 16 & 9.70 & 0.50 & 3.213 & 28 & $.003^{*}$ \\
& Control & 14 & 10.30 & 0.52 & & & \\
Fluency & Experimental & 16 & 10.83 & 0.52 & 4.213 & 28 & $.000^{*}$ \\
& Control & 14 & 11.66 & 0.56 & & & \\
Originality & Experimental & 16 & 8.34 & 0.51 & 2.862 & 28 & $.008^{*}$ \\
& Control & 14 & 8.88 & 0.51 & & & \\
Elaboration & Experimental & 16 & 6.70 & 0.45 & 1.587 & 28 & .124 \\
& Control & 14 & 6.98 & 0.51 & & & \\
\hline
\end{tabular}

${ }^{*} \mathrm{p}<.05$

Table 1 indicates significant difference $(p<.05)$ between pre-test results of experimental and control groups with values of $t=3.21$ for flexibility, $t=4.21$ for fluency and $t=2.86$ for originality dimension excluding $p>.05$ for elaboration dimension $t=1.58$. It was also seen that mean values of the children in control group show higher performance in flexibility, fluency and originality dimensions.

Table 2

ANCOVA Results Concerning Mean Values of the Post-test of Experimental and Control Groups Obtained from Creative Behavior Observation Form

\begin{tabular}{llllllll}
\hline $\begin{array}{l}\text { Dimensions of } \\
\text { Creativity }\end{array}$ & Group & $\mathrm{N}$ & $\mathrm{M}$ & $\begin{array}{l}\text { Adjusted } \\
\text { Means }\end{array}$ & SS & F & P \\
\hline Flexibility & Experimental & 16 & 16.64 & 16.89 & 0.75 & 234.952 & $.000^{*}$ \\
& Control & 14 & 11.59 & 17.84 & 0.95 & & \\
Fluency & Experimental & 16 & 17.70 & 12.99 & 0.63 & 176.350 & $.000^{*}$ \\
& Control & 14 & 13.41 & 11.72 & 1.00 & & \\
Originality & Experimental & 16 & 12.83 & 11.29 & 0.64 & 104.958 & $.000^{*}$ \\
& Control & 14 & 9.96 & 13.13 & 0.83 & & \\
Elaboration & Experimental & 16 & 11.06 & 9.78 & 0.46 & 357.986 & $.000^{*}$ \\
& Control & 14 & 7.61 & 7.48 & 0.63 & & \\
\hline$* 0<05$ & & & & & & &
\end{tabular}

${ }^{*} \mathrm{p}<.05$

Results of post-test in Table 2 show that children in the experimental group had meaningful scores when mean values for all dimensions of experimental and control group were compared $(\mathrm{p}<.05)$. After the effects of pre-test were removed, differences between mean values of experimental and control groups were analyzed through adjusted mean values of ANCOVA, which indicate significant differences at $\mathrm{p}<.05$ level in favor of experimental group in all dimensions of creativity. This finding demonstrated that, in all dimensions, mean values collected from experimental group was higher than those collected from control group. 
Table 3

Paired Samples $t$ Test Results Concerning Mean Values of Pre-test/Post-test Obtained from Creative Behavior Observation Form for Experimental Group

\begin{tabular}{llllllll}
\hline $\begin{array}{l}\text { Dimensions of } \\
\text { Creativity }\end{array}$ & Criteria & $\mathrm{N}$ & $M$ & $\mathrm{SS}$ & $\mathrm{t}$ & $\mathrm{sd}$ & $\mathrm{p}$ \\
\hline Flexibility & Pre-test & 16 & 9.70 & 0.50 & 32.132 & 15 & $.000^{*}$ \\
& Post-test & 16 & 16.64 & 0.75 & & & \\
Fluency & Pre-test & 16 & 10.83 & 0.52 & 35.502 & 15 & $.000^{*}$ \\
& Post-test & 16 & 17.70 & 0.63 & & & \\
Originality & Pre-test & 16 & 8.34 & 0.51 & 21.508 & 15 & $.000^{*}$ \\
& Post-test & 16 & 12.83 & 0.64 & & & \\
Elaboration & Pre-test & 16 & 6.70 & 0.45 & 27.297 & 15 & $.000^{*}$ \\
& Post-test & 16 & 11.06 & 0.46 & & & \\
\hline
\end{tabular}

${ }^{*} \mathrm{p}<.05$

It is seen in Table 3 that there were significant differences $(p<.05)$ in favor of post-test. when pre-test/post-test scores in all dimensions of the children in the experimental group were evaluated through Creative Behavior Observation Form with values of $t=32.13$ for flexibility, $t=35.50$ for fluency, $t=21.50$ for originality and $t=27.29$ for elaboration dimension.

Table 4

Paired Samples $t$ Test Results Concerning Mean Values Obtained from Creative Behavior Observation Form for Control Group

\begin{tabular}{llllllll}
\hline $\begin{array}{l}\text { Dimensions of } \\
\text { Creativity }\end{array}$ & Criteria & $\mathrm{N}$ & $M$ & $\mathrm{SS}$ & $\mathrm{t}$ & $\mathrm{sd}$ & $\mathrm{P}$ \\
\hline Flexibility & Pre-test & 14 & 10.30 & 0.52 & 5.956 & 13 & $.000^{*}$ \\
& Post-test & 14 & 11.59 & 0.95 & & & \\
Fluency & Pre-test & 14 & 11.66 & 0.56 & 8.158 & 13 & $.000^{*}$ \\
& Post-test & 14 & 13.41 & 1.00 & & & \\
Originality & Pre-test & 14 & 8.88 & 0.51 & 5.843 & 13 & $.000^{*}$ \\
& Post-test & 14 & 9.96 & 0.83 & & & \\
Elaboration & Pre-test & 14 & 6.98 & 0.51 & 5.827 & 13 & $.000^{*}$ \\
& Post-test & 14 & 7.61 & 0.63 & & & \\
\hline
\end{tabular}

${ }^{*} \mathrm{p}<.05$

As seen in Table 4, mean values of the post-test of the children in the control group showed more increase $(\mathrm{p}<.05)$ than pre-test with values of $t=5.95$ for flexibility, $t=8.15$ for fluency, $t=5.84$ for originality and $t=5.82$ for elaboration dimension in the Creative Behavior Observation Form. 
Table 5

Paired Samples $t$ Test Results Concerning Mean Values Obtained from Creative Behavior Observation Form for Experimental Group

\begin{tabular}{llllllll}
\hline $\begin{array}{l}\text { Dimensions of } \\
\text { Creativity }\end{array}$ & Criteria & $\mathrm{N}$ & $\mathrm{M}$ & $\mathrm{SS}$ & $\mathrm{t}$ & $\mathrm{sd}$ & $\mathrm{P}$ \\
\hline Flexibility & Post-test & 16 & 16.64 & 0.75 & 2.360 & 15 & .132 \\
& Retention & 16 & 16.53 & 0.58 & & & \\
Fluency & Post-test & 16 & 17.70 & 0.63 & 3.033 & 15 & .210 \\
& Retention & 16 & 17.60 & 0.72 & & & \\
Originality & Post-test & 16 & 12.83 & 0.64 & 1.246 & 15 & $.021^{*}$ \\
& Retention & 16 & 12.92 & 0.44 & & & \\
Elaboration & Post-test & 16 & 11.16 & 0.46 & 2.416 & 15 & .192 \\
& Retention & 16 & 11.23 & 0.27 & & & \\
\hline
\end{tabular}

${ }^{*} \mathrm{p}<.05$

Table 5 demonstrated that there was no significant difference $(\mathrm{p}<.05)$ between mean values of the post-test and retention assessment with values of $t=2.36$ for flexibility, $t=3.03$ for fluency, $t=2.41$ for elaboration dimension in Creative Behavior Observation Form of experimental group. As seen in Table 5, mean values were very close to each other in all dimensions, which indicated that Creativity Training Program applied to preschool children had retentive effect on the creative behaviors of the children.

Table 6

Results of reliability analysis of the mean values obtained from four dimensions in Creative Behavior Observation Form by researcher and secondary observer

\begin{tabular}{llllll}
\hline Group & Variables & Flexibility & Fluency & Originality & Elaboration \\
\hline Control & Post-test & 0.914 & 0.826 & 0.945 & 0.966 \\
Group & Post-test & 0.922 & 0.927 & 0.962 & 0.972 \\
Experimental & Post-test & 0.986 & 0.926 & 0.896 & 0.963 \\
Group & Post-test & 0.963 & 0.901 & 0.987 & 0.972 \\
& Retention & 0.896 & 0.869 & 0.859 & 0.815 \\
\hline
\end{tabular}

$\mathrm{p}>0.001$

In Table 6, all correlation coefficients between primary and secondary observers were high. All coefficients were higher than 0.80 value and meaningful at 0.001 level ( $p>0.001)$, which implied high consistency between primary and secondary observers. When two observers assessed their own observations based on a scaling instrument with variables from one to five, it was a beneficial method to apply Pearson Correlation in order to understand if there was any difference between two observers (Hallgren, 2012). 


\section{Discussion and Recommendations}

Creativity starts to develop at preschool period and creative activities underpin preschool education program. While it is aimed to maximize development of the children in terms of their cognitive, physical, social-cultural and linguistic capabilities and self-care, it is also necessary to support their creativity. Therefore, educators have great responsibilities to ensure that creativity of preschool children develop.

Creative behaviors of the children in the experimental group showed significant increase in all dimensions of creativity based on Creativity Training Program. It is believed that children in the experimental group had higher score since their 36 activities following methods such as analogy formation, answer-questions, problem solving, and demonstration, brain storming and story-telling.

Alfonso-Benlliure et al. (2013) applied six weeks Creativity Training Program to preschool children. Results of the study demonstrated that Creativity Training Program was effective in developing creativity of the children. Cheung (2013) undertook creative activities so as to investigate efficacy of the creativity training applied to the teachers on the creative abilities of the children. Results showed that creative activities positively affect creativity behaviors of the children. Akçum (2005) also studied effects of preschool education on the creativity. Results of the study imply that creativity score of the children who attended a preschool institution is higher than those do did not. Creativity Training Program was undertaken by Yıldiz (2000) for preschool children and its effects were analyzed. At the end of the training program, results again indicated that Creativity Training Program has positive effects on cognitive development of the children. Oral (1997) studied effects of activity based spiral curriculum on the creative behaviors of 5 years old children and observed significant developments in the creativity of experimental group. Studies undertaken by Akçum; Alfonso-Benlliure et al.; Cheung; Oral and Yıldız have similar findings that this study reached; Creativity Training Program supports and develops creativity of the children.

According to assessments on the retention of experimental group, there was no significant difference between mean values of post-test and retention assessment in terms of flexibility, fluency and elaboration dimension of Creative Behavior Observation Form.

Data collected through the study also implies that Creativity Training Program designed for preschool children positively supports creative behaviors of the children in flexibility, fluency, originality and elaboration dimensions. Furthermore, Creativity Training Program has retentive positive effects on creative behaviors on them.

In line with the findings of this study, following recommendations have been made;

- Creativity Training Program was applied to preschool children in Ankara. Thus, it is possible to apply it to the students who live in other regions. 
- Creativity Training Program was developed for preschool children. Further studies are recommended to focus on different age groups by designing or adapting different activities for primary school children as well as preschool children.

- During the study, it was observed that teachers desired to watch video records again and they were very interested with creativity activities. It is possible to provide presentations about creativity to the teachers and they can be asked to plan various activities in further studies.

\section{References}

Akçum, E. (2005). 5-6 yaş çocuklarının yaratıcılık ve öğrenime hazır oluş düzeylerine okul öncesi eğitimin etkisinin incelenmesi. [The examination of the effect of pre-school education to the levels of creativity and being ready for learning of 5-6 year-old children] (Unpublished Thesis) Selcuk University, Konya.

Alfonso-Benlliure, V., Melendez, J. C., \& Garcia-Ballesteros. M. (2013). Evaluation of a creativity intervention program for preschoolers. Thinking Skills and Creativity, 10, 112- 120. http:/ / dx.doi.org/10.1016/j.tsc.2013.07.005.

Aslan, E. (2001). Kavram boyutunda yaratıcilık. [Creativity in concept dimension] Türk Psikolojik Danışma ve Rehberlik Dergisi, 16(2), 15- 22. Retrieved from file:/ / / C:/Users/ Acer/Downloads/322-735-1-SM.pdf.

Brown, R. (1989). Creativity what are we to measure? Glover, J. A.; Royce, R. R., \& Reynolds, C. R. (Ed). (3- 32). Handbook of creativity. New York: Plenum Press.

Büyüköztürk, Ş. (2007). Deneysel desenler: ön test-son test kontrol grubu desen ve veri analizi. [Experimental patterns pre-test post-test control group pattern and data analysis] (2nd Ed.). Ankara: Pegem A Publishing.

Cheung, R. H. P. (2013). Exploring the use of the pedagogical framework for creative practice in preschool settings: A phenomenological approach. Thinking Skills and Creativity, 10, 133- 142. http://dx.doi.org/10.1016/j.tsc.2013.08.004.

Cheung, R.H. P. (2010). Designing movement activities to develop children's creativity in early childhood education. Early Child Development and Care, 180(3), 377- 385. http:/ / dx.doi.org/10.1080/03004430801931196.

Csikszentmihalyi, M. (1997). Creativity: Flow and the psychology of discovery and invention. New York: Harper Perrential.

Dziedziewicz, D., Oledzka, D., \& Karwowski, M. (2013). Developing 4-to 6-year-old children's figural creativity using 'a doodle-book program. Thinking Skills and Creativity, 9, 85- 95. http:// dx.doi.org/10.1016/j.tsc.2012.09.004.

Gerrig, R. J., \& Zimbardo. P. G. (2005). Psychology and Life. USA: Pearson.

Guilford, J. P. (1976). Traits of Creativity. Vernon P.E. (Ed.). (167-188). Creativity. Harmondsworth: Penguin.

Hallgren, K. A. (2012). Computing inter-rater reliability for observational data: An overview and tutorial. Tutor Quant Methods Psychol, 8(1), 23- 34. Retrieved from https:/ / www.ncbi.nlm.nih.gov/pmc/articles/PMC3402032/. 
Karasar, N. (2008). Bilimsel araştırma yöntemi. [Scientific Research Methods]. Ankara: Nobel Press.

Koster, J. B. (2001). Growing Artists Teaching Art to Young Children. (2nd Ed.). Albany: Delmar.

Mayesky, M. (2002). Creative Activities for Young Children. (7th Ed.). Usa: Thomson Delmar Learning.

MEB (2013). Milli eğitim bakanlığ1 temel eğitim genel müdürlüğü okul öncesi eğitim programı. [Ministry of National Education General Directorate of Preschool Education. Pre-School Education Program]. Retrieved from https://tegm.meb.gov.tr/dosya/okuloncesi/ooproram.pdf.

Myers, D. G. (2004). Psychology. (7 Ed.). New York: Worth Publishers.

Oral, G. (1997). Etkinlik temelli spiral öğretim programının 5 yaş çocuklarına yaratıcılıkları ile aile ve öğretmen gözüyle davranışlarnna etkisi. [The effect of the activity based spiral curriculum on five year-old children's creativity and behaviors as perceived by their parents and teachers]. (Unpublished Thesis) Middle East Technical University, Ankara.

Rizi, C. B., Yarmohamadiyan, M. H., \& Gholami, A. (2011). The effect group plays on the development of the creativity of six-year children. Procedia Social And Behavioral Sciences, 15, 2137- 2141. https:/ / doi.org/10.1016/j.sbspro.2011.04.067.

Sawyer, R.K. (2012). Explaining creativity: the science of human innovation. New York: Oxford University Press.

Schirrmacher, R. (2006). Art and creative development for young children. (7th Ed.). USA: Thomson Delmar Learning.

Shaffer, D. R., \& Kipp. K. (2007). Developmental psychology childhood \& adolescence. Belmont: Thomson Higher Education.

Sungur, N. (1997). Yaratıcı düşünme. [Creative thought]. İstanbul: Evrim Publications.

Torrance, E. P. (1962). Guiding creative talent. New Jersey: Prentice-Hall.

Torrance, E. P. (1977). Creativity in the Classroom. Washington: National Education Association.

Torrance, E. P. (2004). Great expectations: creative achievements of the sociometric stars in a 30-year study. The Journal of Secondary Gifted Education, 16(1), 5-13. https:/ / doi.org/10.4219/jsge-2004-465.

Truman, S. (2011). A generative framework for creative learning: a tool for planning creative-collaborative tasks in the classroom. Retrieved from:

http://www.regents.ac.uk/media/448147/1101_generative_framework_truma n.pdf.

Yıldız, F. Ü. (2000). Deneysel yaratıcılık programının 4-5 yaş çocuklarının sosyal ve bilişsel gelişimlerine etkileri. [Social and cognitive developmental effects of 4-5 years old children in experimental creativity program). (Unpublished Thesis) Selcuk University, Konya. 


\section{Özet}

\section{Giriş}

Birçok kuramcı çalışmalarında yaratıcılığı tanımlamış ve yaratıcılığı geliştirici yöntemler üzerinde çalışmıştır. Yaratıcılık, ayrıştırıcı düşünme sürecinde akıcılık ve bileşenlerin dişında bir işlem yapma olarak tanımlanmaktadır (Guilford, 1976, s. 168). Torrance ise yaratıcılığ1, yetenekler, beceriler, motivasyon ve bir problemle başa çıkmada kurulan bağlantılar bütünü olarak tanımlamaktadır (Torrance, 2004).

Yaratıcılık, özgün bir ürün olan veya ürüne dönüşmemiş olan, problem çözme sürecini içeren, bireyin zekasını özgün biçimde üretmeye dönük kullandığı bilişsel bir beceridir (Aslan, 2001, s. 15; Sawyer, 2012, s. 30). Bu nedenle, bireyin bilişsel gelişim düzeyinin yaratıcılık için yeterli olması gerekmektedir (Shaffer ve Kipp, 2007, s. 372). Diğer bir unsur motivasyondur. Birey, bir ürün elde ederken odaklandığında daha fazla yaratıcı olabilir. Risk alma, karmaşık durumları çözme çabası ve yaratıcı olmaya isteklilik de yaratıcılığın bir başka özelliğidir. Son unsur ise destekleyici bir çevredir. Çocuklara özel yeteneklerin desteklendiği, yaratıcı olmaya teşvik edici bir çevrenin sunulması gerekmektedir (Myers, 2004, s. 429). Diğer bir deyişle yaratıcılık, tutum, süreçler, ürün, yetenek ve çevre koşullarının bir araya gelmesiyle oluşmaktadır (Brown, 1989, s. 3; Schirrmacher, 2006, s. 5).

\section{Yöntem}

$\mathrm{Bu}$ araştırmada anasınıfına devam eden çocuklara uygulanan yaratıcılık eğitim programının, çocukların yaratıcı davranışlarına etkisinin incelenmesi amaçlanmıştır.

Araştırmanın çalışma grubunu, amaçlı örnekleme türlerinden tipik durum örneklemesi yöntemiyle seçilen iki farklı okulun anasınıfında eğitim gören 30 çocuk oluşturmaktadır. Araştırmanın deney grubunda 16, kontrol grubunda da 14 çocuk bulunmaktadır. Her iki gruptaki çocuklara ön-test ve son-test olarak araştırmacı tarafından Yaratıcı Davranış Gözlem Formu Etkinliklerinin yaklaşık 60 dakika süren etkinlikleri dört gün boyunca, sıra ile uygulanmıştır. Etkinliklerin çekimlerinin videokasete eksiksiz ve tam olarak kaydedilmesi amacıyla ikinci gözlemci belirlenmiştir. Ardından deney ve kontrol grubundaki çocukların davranışları Yaratıcı Davranış Gözlem Formu iki gözlemci ile değerlendirilmiştir.

Deney grubundaki çocukların yaratıcılıklarını desteklemeye yönelik Yaratıcılık Eğitim Programı araştırmacı tarafından uygulanmıştır. Kontrol grubundaki çocuklara ise anasınıfı öğretmeni tarafından Milli Eğitim Bakanlığı Okul Öncesi Eğitim Programı'nın uygulanmasına devam edilmiştir.

Son testlerin uygulanmasının ardından, Yaratıcılık Eğitim Programı'nın kalıcılığını belirlemek için deney grubuna Yaratıcı Davranış Gözlem Formu Etkinlikleri tekrar uygulanmıştır ve çocukların davranışları Yaratıcı Davranış Gözlem Formu' na ikinci gözlemci ile ayrı ayrı değerlendirilmiştir. 


\section{Bulgular}

Verilerin analizi kısmında öncelikle, verilerin normal dağılımı sağlayıp sağlamadığı incelenmiştir. Veriler normal dağılım gösterdiği için parametrik istatistiksel analiz yöntemleri kullanılmıştır.

Kontrol grubu ve deney grubunun gözlem formundan aldıkları ön-test ve sontest ortalamaları arasında anlamlı farklılık olup olmadığını belirlemek için ilişkili örneklemler $\mathrm{t}$ testi, kontrol grubunun ve deney grubunun ön-test ortalamaları arasında fark olup olmadığını belirlemek için bağımsız örneklemler $\mathrm{t}$ testi, kontrol ve deney grubunun ön-test sonuçları arasında anlamlı fark bulunan boyutlardan elde edilen son-test ortalamalarını karşılaştırmak için ANCOVA, kullanılarak veriler analiz edilmiştir.

Birinci ve ikinci gözlemci arasındaki tutarlılık Pearson korelasyon katsayısı ile belirlenmiştir. Çalışmada tüm analizler için anlamlılık düzeyi $p<.05$ olarak belirlenmiştir.

\section{Tartışma}

Yaratıcılık Eğitim Programı'na katılan çocukların yaratıcılık puanları kontrol grubundaki çocuklardan daha yüksektir. Elde edilen verilere göre, Yaratıcılık Eğitim Programı çocukların yaratıcı davranışlarını olumlu yönde geliştirmektedir. Kalıcılık testi sonuçlarına göre de Yaratıcılık Eğitim Programı'nın etkisi devam etmektedir.

\section{Öneriler}

Elde edilen verilerle, çocukların yaratıcılıklarının geliştirilmesine katkıda bulunmak amacıyla araştırmacılara ve öğretmenlere yönelik öneriler geliştirilmiştir.

- Yaratıcılık Eğitim Programı Ankara'da anasınıfına devam eden çocuklara uygulanmıştır. Bu nedenle, bundan sonraki araştırmalarda farklı bölgelerde yaşayan çocuklara Yaratıcılık Eğitim Programı uygulanabilir.

- Yaratıcılık Eğitim Programı anasınıfına devam eden çocuklar için geliştirilmiştir. Bundan sonraki araştırmaların anaokuluna giden çocuklara, ilköğretim dönemindeki çocuklara yönelik farklı etkinlikler planlanarak veya adapte ederek farklı yaş gruplarında çalışılması uygun önerilmektedir.

- Öğretmenlerin yaratıcılıkla ilgili tutum ve davranışlarını belirleyen çalışmaların olmadığı görülmektedir. Bu nedenle, yapılan araştırmalarda, öğretmenlerin yaratıcılıkla ilgili tutum ve davranışlarının neler olduğunu belirleyen bir ölçüm aracı geliştirilebilir.

- Araştırma yapılırken öğretmenlerin video çekimlerini tekrar izlemek istediği görülmüş ve yaratıcılıkla ilgili etkinliklere çok ilgili olduklarına dikkat edilmiştir. Bundan sonraki araştırmalarda öğretmelere yaratıcılıkla ilgili eğitimler sunulup öğretmenlerden farklı etkinlikler planlamaları istenebilir. 


\section{Author's Biodata/Yazar Bilgileri}

Zeynep DERE, Bozok Üniversitesi Eğitim Fakültesi’nde Dr. Öğretim Üyesi olarak görev yapmaktadır.

Zeynep Dere, is an Assist. Ph.D. Professor at Bozok University, Faculty of Education.

Esra ÖMEROĞLU, Gazi Üniversitesi Eğitim Fakültesi’nde Profesör Doktor olarak görev yapmaktadır.

Esra Ömeroğlu, is a Ph.D. Professor at Gazi University, Faculty of Education. 